\title{
FOLFOX regimen plus dendritic cells-cytokine- induced killer cells immunotherapy for the treatment of colorectal cancer: a meta-analysis
}

This article was published in the following Dove Press journal:

OncoTargets and Therapy

18 May 2017

Number of times this article has been viewed

\author{
Yan Liu' \\ Zhong Zheng' \\ Qixin Zhang ${ }^{2}$ \\ Xinling Zhou ${ }^{3}$ \\ Yikuan Feng' \\ Anquan Yan ${ }^{2}$ \\ 'Department of Gastroenterology, \\ ${ }^{2}$ Department of Health Care, \\ ${ }^{3}$ Digestive Endoscopy Center, Weifang \\ People's Hospital, Weifang, China
}

Correspondence: Anquan Yan Department of Health Care, Weifang People's Hospital, I5I Guangwen Street, Weifang 26104I, Shandong, China

Tel +86 I3793670380

Emailwfrmyyaq@163.com
Purpose: To systematically investigate the efficacy and safety of the combination of FOLFOX (oxaliplatin, 5-fluorouracil, and leucovorin) regimen and cocultured dendritic cells and cytokineinduced killer cells (DC-CIK) immunotherapy for the treatment of colorectal cancer (CRC).

Methods: Publications reporting the clinical trials' responses or safety of FOLFOX regimen combined with DC-CIK immunotherapy in treating CRC patients were searched in PubMed, Embase, Cochrane Library, China National Knowledge Internet, and Wanfang databases. Trials meeting the selection criteria were analyzed. The overall survival (OS), overall response rate (ORR), disease control rate (DCR), tumor markers, immune function, and adverse events were evaluated.

Results: Ten trials including $881 \mathrm{CRC}$ patients were analyzed in this meta-analysis. The combined therapy showed advantages over FOLFOX treatment-alone in 2-year OS (odds ratio $[\mathrm{OR}]=2.77$, confidence interval $[\mathrm{CI}]=1.58-4.86, P=0.0004), \mathrm{ORR}(\mathrm{OR}=1.85, \mathrm{CI}=1.34-2.56$, $P=0.0002)$, and DCR (OR $=2.54, \mathrm{CI}=1.76-3.67, P<0.00001)$, with statistical significance. After immunotherapy, lymphocyte subset percentages of $\mathrm{CD}^{+}(P=0.0006)$ and $\mathrm{CD}^{+}(P=0.01)$, $\mathrm{CD}^{+} / \mathrm{CD}^{+}$ratio $(P=0.0003)$, and levels of cytokines IFN- $\gamma(P=0.003)$ and IL-2 $(P=0.01)$ were significantly increased, whereas analysis of $\mathrm{CD} 8^{+}, \mathrm{CD}^{-} \mathrm{CD}^{-} 6^{+}, \mathrm{CD}^{+} \mathrm{CD} 56^{+}, \mathrm{CD} 4^{+} \mathrm{CD} 25^{+}$, IL-6, and TNF- $\alpha$ did not show any significant difference $(P>0.05)$. Moreover, the level of carcinoembryonic antigen was also decreased significantly upon immunotherapy $(P<0.00001)$.

Conclusion: The combination of FOLFOX regimen and DC-CIK immunotherapy was safe and effective for CRC patients.

Keywords: FOLFOX, dendritic cells, cytokine-induced killer cells, colorectal cancer, meta-analysis

\section{Introduction}

Colorectal cancer $(\mathrm{CRC})$ is the second most frequent cause of death in Europe and North America with about 600,000 deaths per year. ${ }^{1,2}$ In recent years, the incidence of CRC has risen significantly with $\sim 1.2$ million new cases being diagnosed every year worldwide, while the 5-year survival rate of patients with stage IV CRC is $<10 \%{ }^{1-4}$ Chemotherapy is the main treatment for $\mathrm{CRC}$, and appropriate chemotherapy regimens effectively prolong patients' lives and improve their quality of life. ${ }^{2,4}$ FOLFOX (oxaliplatin, 5-fluorouracil, and leucovorin) is one of the most common chemotherapy regimens and is a standard first-line therapy for CRC. ${ }^{1,5}$ However, many researchers have reported that chemotherapy alone was not able to completely eradicate small lesions and metastatic cells, which may raise the probability of cancer recurrence. ${ }^{6}$ Comprehensive treatments are therefore taken as the future for CRC therapy, and the 
combination of chemotherapy and adoptive cell therapy is one of the options.

Adoptive cellular immunotherapy is achieved upon in vitro expansion of autologous immune effector cells, such as cytokine-induced killer cells (CIK), ${ }^{7,8}$ natural killer cells ${ }^{9}$ and other immune cells, ${ }^{10-12}$ and transfusion back to the patients. Since conventional therapies are not able to eradicate the tumor cells thoroughly, the killing effect of adoptive cellular immunotherapy on tumor cells will make it an important supplement. ${ }^{8} \mathrm{CIK}$ is a heterogeneous subset which consists primarily of $\mathrm{CD}^{+} \mathrm{CD}^{+} 6^{+}$and can be easily induced from peripheral blood mononuclear cells. ${ }^{7,8}$ Compared with other immune cells, CIK show a broader antitumor spectrum and a stronger antitumor ability. ${ }^{13}$ Dendritic cells (DC) are the most potent antigen-presenting cells. ${ }^{14}$ Studies have shown that coculture with DC enhances the cytotoxicity of CIK, indicated by an increased proportion of $\mathrm{CD} 3{ }^{+} \mathrm{CD} 56^{+}$cells and improved levels of cytokines such as IL-2, IFN- $\gamma$, IL-12, and TNF- $\alpha{ }^{15-18}$ It has also been found that the combination of DC and CIK is more effective than CIK treatment. ${ }^{8}$

Chemotherapy combined with adoptive immunotherapy has shown satisfactory therapeutic effects in treating patients with advanced CRC. ${ }^{19-21}$ In a meta-analysis of treating advanced CRC with CIK or DC-CIK combined with chemotherapy or chemotherapy alone, the former showed significantly improved overall survival (OS) and overall response rate (ORR), while safety, tumor markers, and levels of cytokines were not involved in this analysis. ${ }^{22}$ Moreover, the therapeutic regimens among studies were different, which may have influenced the analysis of clinical therapy. In the present study, a more stringent inclusion criterion (only CRC patients treated by FOLFOX regimen with DC-CIK immunotherapy were included) was developed to exclude the impact of different treatments on the clinical efficacy. Meanwhile, a systematic review and meta-analysis were carried out to investigate the efficacy and safety of FOLFOX chemotherapy combined with DC-CIK immunotherapy in comparison with FOLFOX alone, in order to provide scientific evidence for future clinical trials.

\section{Materials and methods}

\section{Search strategy and selection criteria}

Literature was searched in PubMed, Embase, Cochrane Library, China National Knowledge Internet, and Wanfang databases with key terms "dendritic cells" and "cytokineinduced killer cells" combined with "colorectal cancer." No language limits were applied. The initial search was performed in January 2016 and updated in July 2016.
The study inclusion criteria were as follows: 1) randomized controlled trials in CRC patients and 2) patients in the experimental group received FOLFOX regimen combined with DC-CIK immunotherapy, and patients in the control group were treated by FOLFOX alone.

\section{Data collection and quality assessment}

Data were extracted by two researchers independently (Yan Liu and Zhong Zheng), and discrepancy was resolved upon discussing with a third researcher (Qixin Zhang). Extracted information included first author's names, years of publication, study locations, tumor stages, numbers of subjects, patient ages, in vitro cell culture conditions, and dosages of utilized immune cells. The quality of the included papers was evaluated based on Cochrane Handbook. ${ }^{23}$

\section{Definition of measurements}

Treatment efficacy was assessed in terms of OS, complete response rate (CR), partial response rate $(\mathrm{PR})$, stable disease rate $(\mathrm{SD})$, progressive disease rate $(\mathrm{PD}), \mathrm{ORR}(\mathrm{ORR}=\mathrm{CR}+$ $\mathrm{PR})$, and disease control rate (DCR; $\mathrm{DCR}=\mathrm{CR}+\mathrm{PR}+$ $\mathrm{SD})$. OS was defined as the duration from the initiation of treatment to death from any cause. ${ }^{24}$ The immune function of CRC patients before and after treatment was determined by lymphocyte subsets $\left(\mathrm{CD}^{+}, \mathrm{CD}^{+}, \mathrm{CD}^{+}, \mathrm{CD}^{-} \mathrm{CD}^{-} 6^{+}\right.$, $\mathrm{CD}^{+}{ }^{+} \mathrm{CD} 56^{+}$, and $\left.\mathrm{CD} 4^{+} \mathrm{CD} 25^{+}\right)$and cytokines secretion (IFN- $\gamma$, IL-2, IL-6, and TNF- $\alpha$ ). Adverse events during therapy were also taken into an assessment.

\section{Statistical analysis}

The analysis was performed using Review Manager 5.2 (Cochrane Collaboration). $P<0.05$ was considered statistically significant. Heterogeneity among studies was assessed to determine the most suitable analysis model. ${ }^{25}$ Cochran's $Q$ test was performed to evaluate the homogeneity of the results; $I^{2}<50 \%$ or $P>0.1$ indicated that the studies were homogenous. Odds ratio (OR) was the principal measurement for therapeutic effects and is presented with a $95 \%$ confidence interval (CI).

\section{Results}

\section{Search results}

A total of 3,055 articles were identified with the initial retrieve. After reviewing the titles and abstracts, 2,982 articles were excluded because they were not clinical trials $(n=2,593)$ were a duplication or repetition $(n=257)$ or were unrelated studies $(\mathrm{n}=132)$, and 73 studies were selected as potentially relevant. After full-text assessment, 27 studies 


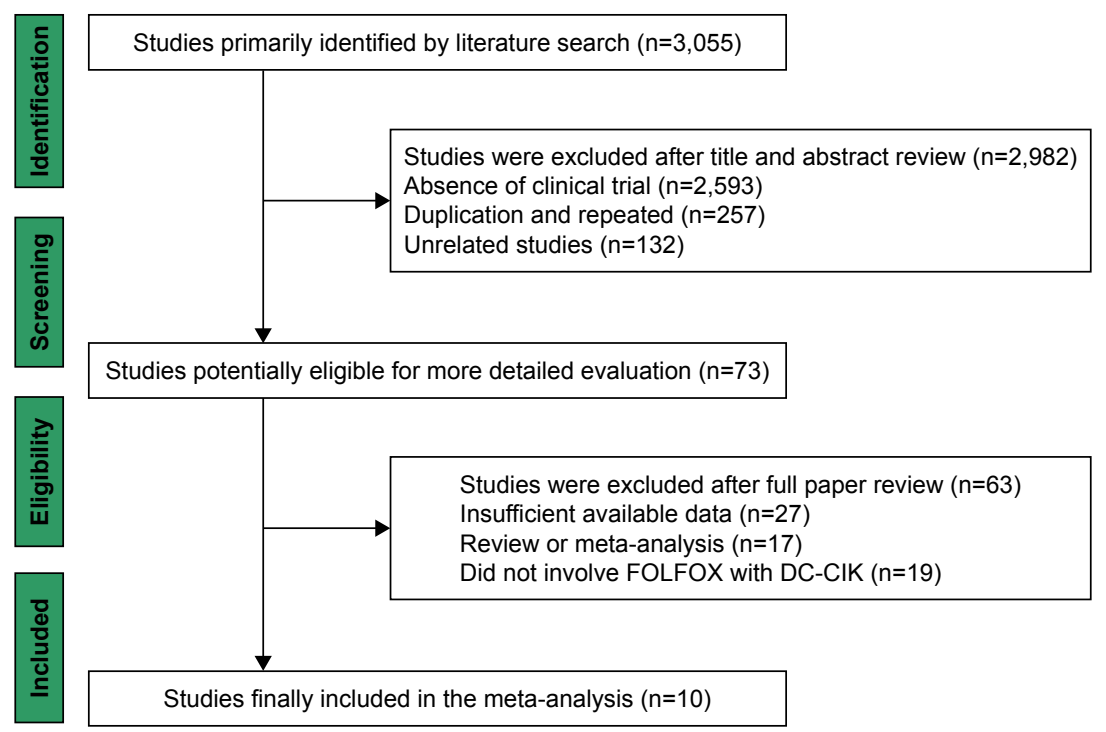

Figure I Flow diagram showing record identification, screening, and study inclusion process.

Abbreviations: FOLFOX, oxaliplatin, 5-fluorouracil, and leucovorin; DC-CIK, dendritic cells and cytokine-induced killer cells.

with insufficient data, 17 reviews or meta-analyses and 19 studies which did not involve FOLFOX regimen and DC-CIK immunotherapy were excluded. Finally, 10 trials including a total of 881 patients were found to be eligible for inclusion in this meta-analysis (Figure 1). ${ }^{26-35}$

\section{Patient characteristics}

All the involved trials were conducted in mainland China. In total, 444 patients were treated by FOLFOX regimen in combination with DC-CIK immunotherapy, and 437 patients were treated by FOLFOX alone. DC and CIK used in the 10 trials were all obtained from autologous peripheral blood. All DC and CIK were examined and confirmed free of bacterial and fungal contamination, and negative for mycoplasma. Cells were cultured for amplification in vitro. The DC and
CIK were suspended in saline containing $2 \%$ albumin (100 or $200 \mathrm{~mL}$ ) and intravenously transfused into patients, except one trial in which DC were subcutaneously transfused. ${ }^{33}$ DC-CIK were transfused for two or more treatment cycles. However, the accurate cell numbers were not provided in most studies. Detailed clinical information on the trials is presented in Tables 1 and 2.

\section{Quality assessment}

The assessment of bias risk is shown in Figure 2. The overall qualities of the involved studies ranged from moderate to high. Eight studies were determined as of low risk, and the remaining two studies did not show a clear description of the randomization process. The risks of allocation, performance, and detection were low; one research was regarded as of

Table I Clinical information from the eligible trials in the meta-analysis

\begin{tabular}{|c|c|c|c|c|c|c|}
\hline \multirow{2}{*}{$\begin{array}{l}\text { Included } \\
\text { studies }\end{array}$} & \multirow[t]{2}{*}{ Nation } & \multirow{2}{*}{$\begin{array}{l}\text { Tumor } \\
\text { stage }\end{array}$} & \multirow{2}{*}{$\begin{array}{l}\text { Patients } \\
\text { Con/Exp }\end{array}$} & \multicolumn{2}{|l|}{ Age (year) } & \multirow[t]{2}{*}{ Parameter types } \\
\hline & & & & Con & Exp & \\
\hline $\operatorname{Bian}^{26}$ & China & ND & $42 / 42$ & $62.2 \pm 4.9($ mean $\pm S D)$ & $62.7 \pm 4.9($ mean $\pm S D)$ & ORR, DCR, LYM subsets, AE \\
\hline $\mathrm{Hou}^{27}$ & China & II-III & $40 / 40$ & $57.4 \pm 3.0($ mean $\pm S D)$ & $56.0 \pm 2.5($ mean $\pm S D)$ & OS, ORR, DCR \\
\hline Li et $\mathrm{al}^{28}$ & China & II-III & $20 / 20$ & $57.5($ mean $\pm S D)$ & $54.5($ mean $\pm S D)$ & OS, LYM subsets, cytokines, AE \\
\hline Li et $\mathrm{al}^{29}$ & China & $\mathrm{Ps} \leq 2$ & $38 / 39$ & $51.6 \pm 13.0($ mean $\pm S D)$ & $53.4 \pm 13.6($ mean $\pm S D)$ & $\begin{array}{l}\text { ORR, DCR, LYM subsets, cytokines, } \\
\text { tumor markers, } A E\end{array}$ \\
\hline Rui et $\mathrm{al}^{30}$ & China & IV & $45 / 45$ & $58.6 \pm 12.6($ mean $\pm S D)$ & $63.3 \pm 10.1($ mean $\pm S D)$ & OS, LYM subsets \\
\hline Wang et $\mathrm{al}^{31}$ & China & III-IV & $42 / 42$ & 54 (median) & 56 (median) & LYM subsets, cytokines \\
\hline Weng et $\mathrm{al}^{32}$ & China & III-IV & $111 / 124$ & 55 (median) & 59 (median) & ORR, DCR, LYM subsets, cytokines, AE \\
\hline Weng et $\mathrm{al}^{33}$ & China & IV & $48 / 41$ & $53($ mean \pm SD) & $52($ mean $\pm S D)$ & OS, ORR, DCR, LYM subsets \\
\hline Yuan et $\mathrm{al}^{34}$ & China & $\mathrm{Kps} \geq 60$ & $21 / 21$ & 58 (median) & 60 (median) & ORR, DCR, LYM subsets \\
\hline Zhou $^{35}$ & China & III-IV & $30 / 30$ & $65.1 \pm 4.5($ mean $\pm S D)$ & $64.1 \pm 4.6($ mean $\pm S D)$ & ORR, DCR, AE \\
\hline
\end{tabular}

Notes: Control group: FOLFOX (oxaliplatin, 5-fluorouracil, and leucovorin)-alone group; Experimental group: FOLFOX regimen plus dendritic cells and cytokine-induced killer cells immunotherapy.

Abbreviations: Con, control group; Exp, experimental group; ND, not determined; Ps, performance status score; Kps, Karnofsky Performance score; ORR, overall response rate; DCR, disease control rate; LYM, lymphocyte; AE, adverse events; OS, overall survival. 
Table 2 Information of DC-CIK immunotherapy

\begin{tabular}{|c|c|c|}
\hline $\begin{array}{l}\text { Included } \\
\text { studies }\end{array}$ & Culture conditions & Cell dose (cycles) \\
\hline $\operatorname{Bian}^{26}$ & IFN- $\gamma$, IL-2, CD28 (CIK); GM-CSF, IL-4, TNF- $\alpha$, PGE-2, IL-I $\beta$ (DC) & ND ( 2 cycles $)$ \\
\hline $\mathrm{Hou}^{27}$ & ND & ND ( 2 cycles $)$ \\
\hline Li et $\mathrm{a}^{28}$ & IFN- $\gamma$, IL-2, CD3 (CIK); GM-CSF, IL-4, IFN- $\gamma$ (DC) & ND (2 cycles) \\
\hline Li et $\mathrm{a}^{29}$ & ND & ND (ND) \\
\hline Rui et al $\left.\right|^{30}$ & IFN- $\gamma$, IL-I $\alpha$, IL-2, CD3 (CIK); GM-CSF, IL-4 (DC) & ND ( $\geq 3$ cycles) \\
\hline Wang et $\mathrm{al}^{31}$ & ND & ND ( $2-3$ cycles $)$ \\
\hline Weng et $\mathrm{a}^{32}$ & ND & ND (3 cycles) \\
\hline Weng et $\mathrm{a}^{33}$ & IFN- $\gamma$, IL-I $\alpha$, IL-2, CD3 (CIK); IFN- $\gamma$, LPS (DC) & $3 \times 10^{7-9} /$ cycle (DC, 2 cycles); $5 \times 10^{9} /$ cycle (CIK, 2 cycles) \\
\hline Yuan et $\mathrm{al}^{34}$ & IFN- $\gamma$, IL-2, IL-I $\alpha$, CD3 (CIK); GM-CSF, IL-4, IFN- $\gamma$, TNF- $\alpha$ (DC) & $>1 \times 10^{6}$ (DC, 4 cycles $) ;>1 \times 10^{10}$ (CIK, 4 cycles $)$ \\
\hline Zhou $^{35}$ & ND & ND ( 2 cycles $)$ \\
\hline
\end{tabular}

Abbreviations: DC-CIK, dendritic cells and cytokine-induced killer cells; CIK, cytokine-induced killer cells; DC, dendritic cells; ND, not determined.

unclear risk for lacking follow-up information; three trials were considered as of unclear risk for selective reporting, while the other four studies were considered as of high risk for missing primary outcome data.

\section{Therapeutic efficacy assessments}

As shown in Figures 3, 4, and S1 and Table 3, the pooled results indicated that patients in experimental group had significantly improved 2-year OS, CR, PR, ORR, and DCR (2-year OS: OR =2.77, CI $=1.58-4.86, P=0.0004$; $\mathrm{CR}: \mathrm{OR}=2.30, \mathrm{CI}=1.11-4.76, P=0.03$; $\mathrm{PR}: \mathrm{OR}=1.53$, $\mathrm{CI}=1.07-2.18, P=0.02$; ORR: $\mathrm{OR}=1.85, \mathrm{CI}=1.34-2.56$, $P=0.0002$; DCR: $\mathrm{OR}=2.54, \mathrm{CI}=1.76-3.67, P<0.00001)$ and significantly decreased $\mathrm{PD}(\mathrm{PD}: \mathrm{OR}=0.39, \mathrm{CI}=0.26-0.57$, $P<0.00001$ ), whereas the 1 -year OS and SD did not show significant difference from control group ( 1 -year OS: $\mathrm{OR}=2.42$, $\mathrm{CI}=0.86-6.79, P=0.09$; $\mathrm{SD}: \mathrm{OR}=1.24$, $\mathrm{CI}=0.87-1.77$, $P=0.24)$. Fixed-effect models were used to analyze the OR rate because of low heterogeneity.

Tumor markers were also analyzed to evaluate the therapeutic effects of combination therapy (Figure 5).
Carcinoembryonic antigen (CEA) was significantly reduced after immunotherapy (OR $=-22.80, \mathrm{CI}=-25.98$ to 19.62 , $P<0.00001$ ), while no significant changes were found in carbohydrate antigen 199 (CA199) and carbohydrate antigen 242 (CA242) (CA199: $\mathrm{OR}=-2.60, \mathrm{CI}=-7.61$ to 2.41 , $P=0.31 ; \mathrm{CA} 242$ : $\mathrm{OR}=-1.00, \mathrm{CI}=-6.07$ to $4.07, P=0.70)$.

\section{Immune function evaluation}

The immune status of patients was examined before and after treatment. After DC-CIK treatment, percentages of $\mathrm{CD}^{+}$and $\mathrm{CD}^{+}$cells and $\mathrm{CD} 4^{+} / \mathrm{CD}^{+}$ratio were significantly increased $\left(\mathrm{CD}^{+}: \mathrm{OR}=5.04, \mathrm{CI}=2.18-7.90, P=0.0006 ; \mathrm{CD}^{+}\right.$: $\mathrm{OR}=3.38, \mathrm{CI}=0.73-6.02, P=0.01 ; \mathrm{CD}^{+} / \mathrm{CD}^{+}: \mathrm{OR}=0.39$, $\mathrm{CI}=0.18-0.60, P=0.0003$ ) (Figure 6), whereas no differences were found in the proportions of $\mathrm{CD}^{+}, \mathrm{CD}^{-} \mathrm{CD}^{-} 6^{+}$, $\mathrm{CD}^{+}{ }^{+} \mathrm{CD} 56^{+}$, and $\mathrm{CD}^{+}{ }^{+} \mathrm{CD} 25^{+}$cells $\left(\mathrm{CD}^{+}\right.$: OR $=-0.30$, $\mathrm{CI}=-3.46$ to $2.86, P=0.85 ; \mathrm{CD}^{-} \mathrm{CD}^{-} 6^{+}: \mathrm{OR}=4.04, \mathrm{CI}=-0.36$ to $8.45, P=0.07 ; \mathrm{CD}^{+} \mathrm{CD}^{+}$: $\mathrm{OR}=1.11, \mathrm{CI}=-1.64$ to 3.85 , $P=0.43 ; \mathrm{CD}^{+}{ }^{\mathrm{CD}} 25^{+}: \mathrm{OR}=-0.29, \mathrm{CI}=-2.40$ to 1.82 , $P=0.79)$. Moreover, the levels of IFN- $\gamma$ and IL-2 were significantly increased after DC-CIK therapy $(\mathrm{IFN}-\gamma: \mathrm{OR}=4.50$,

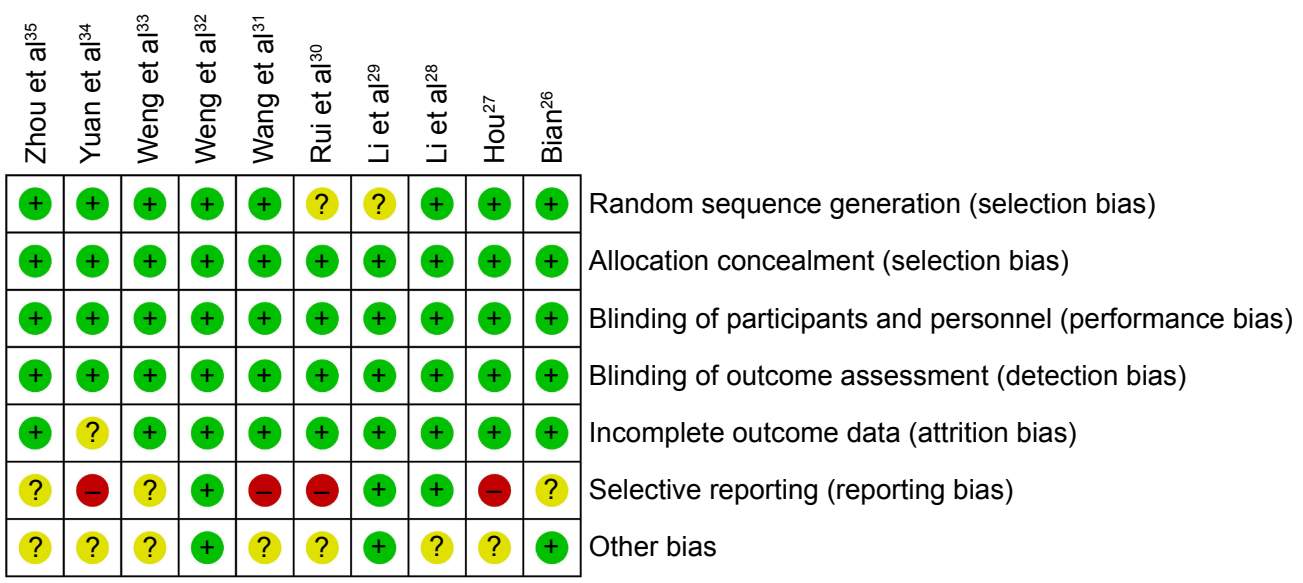

Figure 2 Risk-of-bias summary: review of authors' judgments about each risk-of-bias item for included studies. 


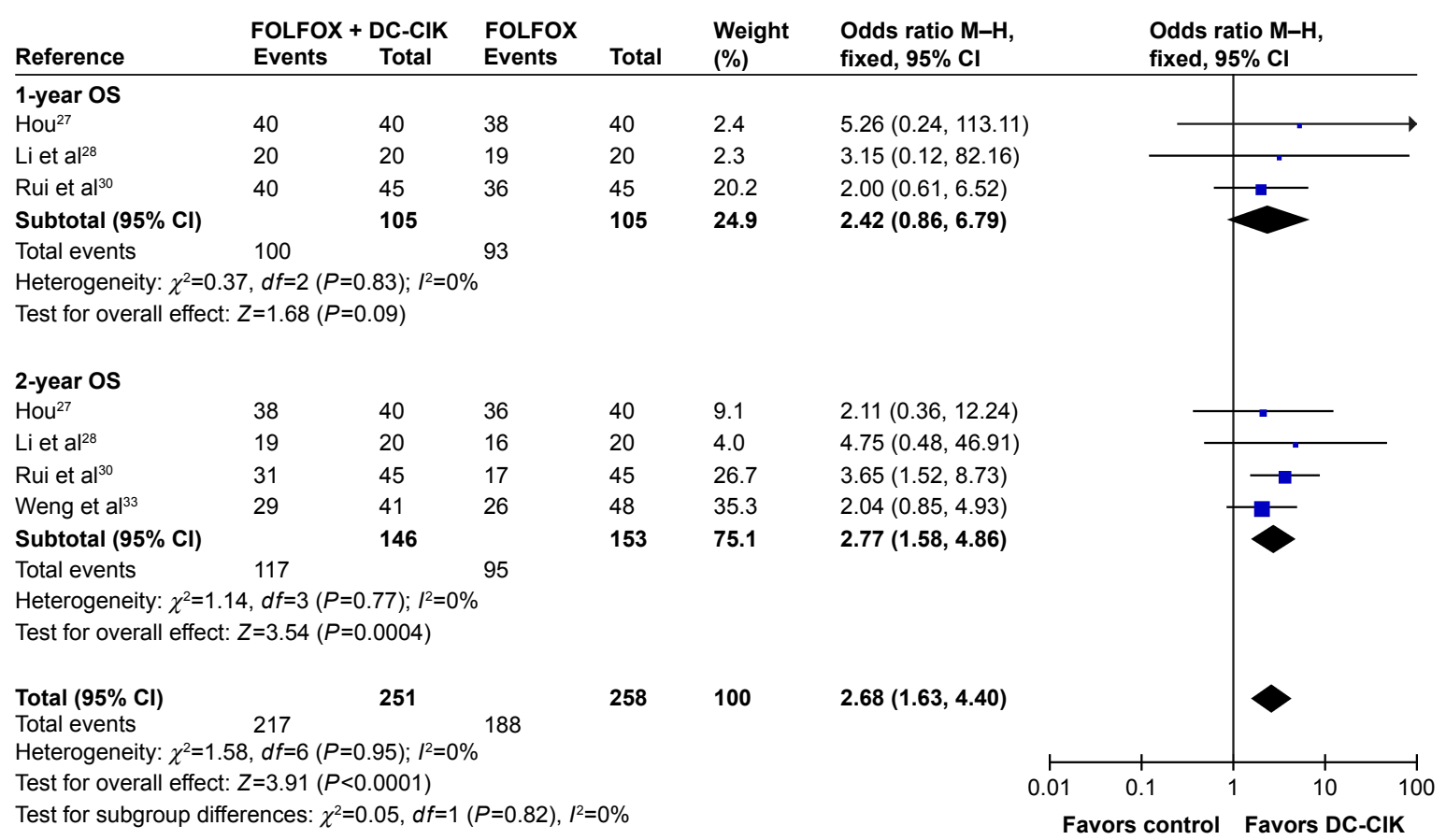

Figure 3 Forest plot of the comparison of OS between the patients who received FOLFOX + DC-CIK therapy and those who received FOLFOX alone. The fixed-effects meta-analysis model (Mantel-Haenszel method) was used.

Abbreviations: OS, overall survival; FOLFOX, oxaliplatin, 5-fluorouracil, and leucovorin; DC-CIK, dendritic cells and cytokine-induced killer cells; M-H, Mantel-Haenszel method; $\mathrm{Cl}$, confidence interval.

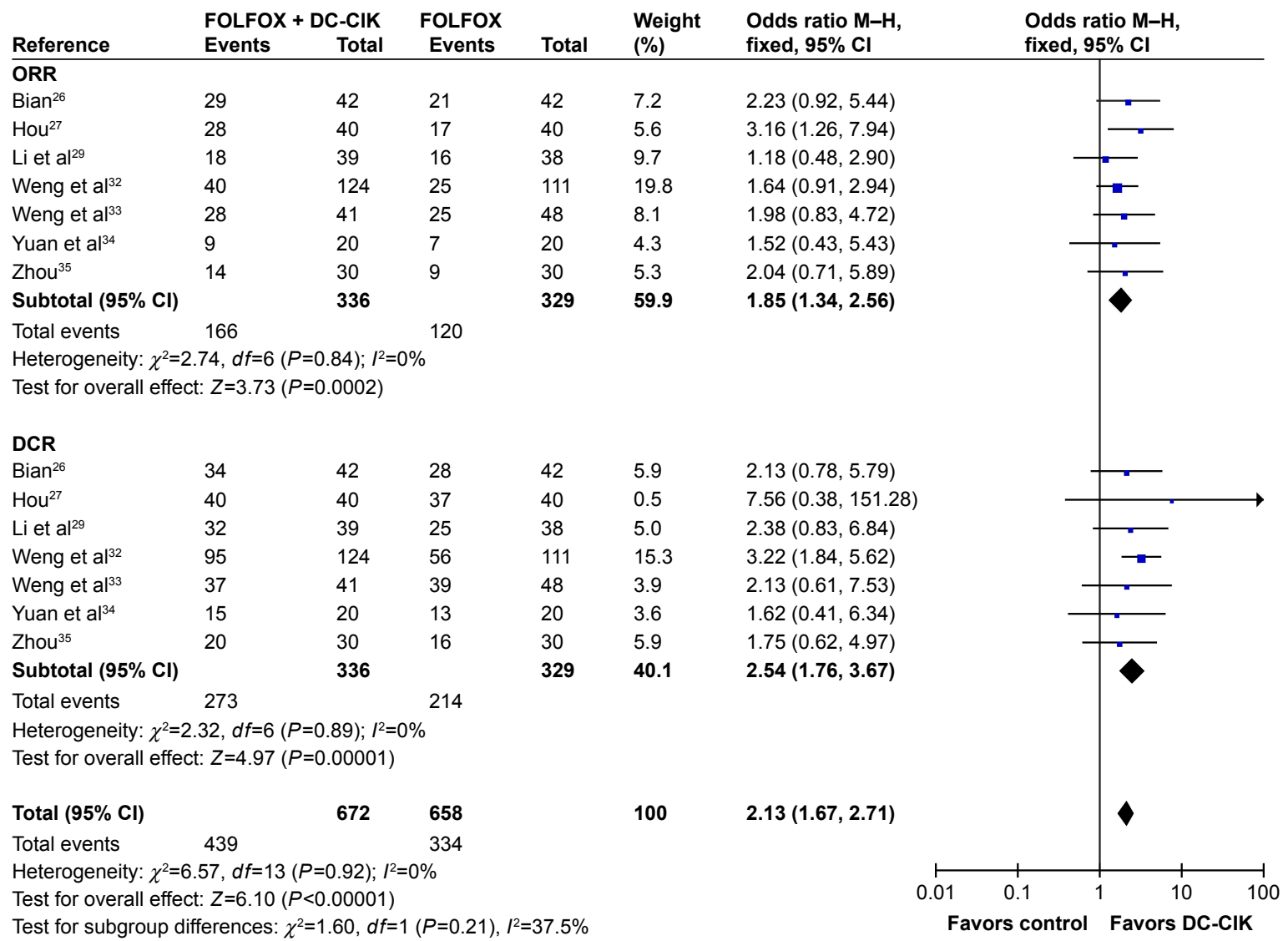

Figure 4 Forest plot of the comparison of ORR and DCR between the patients who received FOLFOX + DC-CIK therapy and those who received FOLFOX alone. The fixed-effects meta-analysis model (Mantel-Haenszel method) was used.

Abbreviations: ORR, overall response rate; DCR, disease control rate; FOLFOX, oxaliplatin, 5-fluorouracil, and leucovorin; DC-CIK, dendritic cells and cytokine-induced killer cells; $\mathrm{M}-\mathrm{H}$, Mantel-Haenszel method; $\mathrm{Cl}$, confidence interval. 
Table 3 Comparison of CR, PR, SD, PD, ORR, and DCR between the FOLFOX + DC-CIK and FOLFOX-alone groups

\begin{tabular}{|c|c|c|c|c|c|c|c|c|}
\hline \multirow[t]{2}{*}{ Parameter } & \multirow{2}{*}{$\begin{array}{l}\text { FOLFOX + DC-CIK } \\
\text { no of patients }(n)\end{array}$} & \multirow{2}{*}{$\begin{array}{l}\text { FOLFOX } \\
\text { no of patients (n) }\end{array}$} & \multirow{2}{*}{$\begin{array}{l}\text { Analysis } \\
\text { method }\end{array}$} & \multicolumn{2}{|c|}{ Heterogeneity } & \multirow[t]{2}{*}{ Odds ratio } & \multirow[t]{2}{*}{$95 \% \mathrm{Cl}$} & \multirow[t]{2}{*}{$P$-value } \\
\hline & & & & $I^{2}(\%)$ & $P$-value & & & \\
\hline CR & 295 & 281 & Fixed & 0 & 0.49 & 2.30 & I.II-4.76 & 0.03 \\
\hline PR & 295 & 281 & Fixed & 0 & 0.93 & 1.53 & $1.07-2.18$ & 0.02 \\
\hline SD & 295 & 281 & Fixed & 52 & 0.06 & 1.24 & $0.87-1.77$ & 0.24 \\
\hline PD & 295 & 281 & Fixed & 0 & 0.81 & 0.39 & $0.26-0.57$ & $<0.00001$ \\
\hline ORR & 336 & 329 & Fixed & 0 & 0.84 & 1.85 & I.34-2.56 & 0.0002 \\
\hline DCR & 336 & 329 & Fixed & 0 & 0.89 & 2.54 & I.76-3.67 & $<0.0000$ I \\
\hline
\end{tabular}

Abbreviations: $C R$, complete response rate; PR, partial response rate; SD, stable disease rate; PD, progressive disease rate; ORR, overall response rate; DCR, disease control rate; FOLFOX + DC-CIK, oxaliplatin, 5-fluorouracil, and leucovorin + dendritic cells and cytokine-induced killer cells; FOLFOX, oxaliplatin, 5-fluorouracil, and leucovorin; $\mathrm{Cl}$, confidence interval.

$\mathrm{CI}=1.57-7.44, P=0.003$; $\mathrm{IL}-2: \mathrm{OR}=1.88, \mathrm{CI}=-0.46-3.30$, $P=0.01$ ) (Figure 7), while no obvious changes were identified in the expression of IL- 6 and TNF- $\alpha$ (IL-6: OR $=-0.81$, $\mathrm{CI}=-2.47$ to $0.86, P=0.34$; TNF- $\alpha$ : $\mathrm{OR}=2.64, \mathrm{CI}=-1.97$ to $7.24, P=0.26$ ).

\section{Adverse events assessment}

As shown in Figure 8, compared with patients treated by FOLFOX alone, those treated by FOLFOX and DC-CIK combined therapy suffered milder myelosuppression and gastrointestinal adverse reactions, but the combined therapy was not able to alleviate leucopenia, thrombocytopenia, nausea and vomiting, liver dysfunction, and peripheral neurotoxicity (myelosuppression: $\mathrm{OR}=0.24, \mathrm{CI}=0.09-0.60, P=0.002$; gastrointestinal adverse reaction: $\mathrm{OR}=0.31, \mathrm{CI}=0.15-0.64$, $P=0.001$; leucopenia: $\mathrm{OR}=0.66, \mathrm{CI}=0.40-1.09, P=0.11$; thrombocytopenia: $\mathrm{OR}=0.71, \mathrm{CI}=0.40-1.24, P=0.23$; nausea and vomiting: $\mathrm{OR}=0.77, \mathrm{CI}=0.44-1.34, P=0.35$; liver dysfunction: $\mathrm{OR}=0.83, \mathrm{CI}=0.41-1.67, P=0.60$; peripheral neurotoxicity: $\mathrm{OR}=0.27, \mathrm{CI}=0.06-1.15, P=0.08$ ).

\section{Discussion}

To date, several clinical trials have been performed using chemotherapy plus DC-CIK immunotherapy for the treatment of CRC. ${ }^{20,21}$ However, the applied clinical protocols were unstandardized in these trials, which made therapeutic effects obscure for evaluation. In this study, a large number of comprehensive trials were investigated to achieve a higher statistical reliability. The meta-analysis revealed that the combination of FOLFOX regimen and DC-CIK immunotherapy improved OS, ORR, DCR, and immune function in CRC patients, without causing severe adverse events.

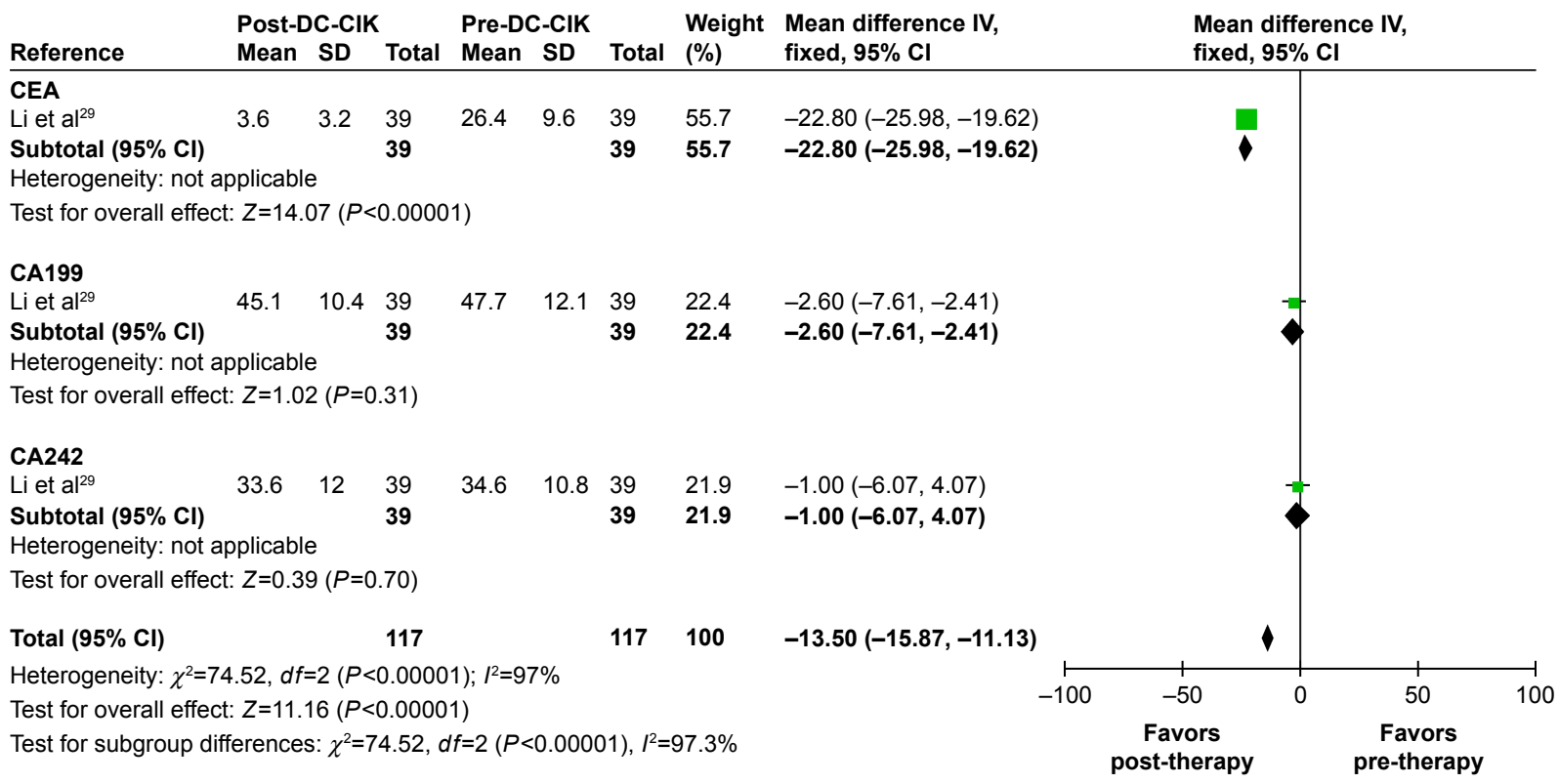

Figure 5 Forest plot of the comparison of tumor markers in pre- and post-DC-CIK immunotherapy. The patient data were obtained before (pre-DC-CIK) and after DC-CIK treatment (post-DC-CIK). The fixed-effects meta-analysis model (IV method) was used.

Abbreviations: DC-CIK, dendritic cells and cytokine-induced killer cells; SD, standard deviation; IV, inverse variance; Cl, confidence interval; CEA, carcinoembryonic antigen; CA199, carbohydrate antigen 199; CA242, carbohydrate antigen 242. 


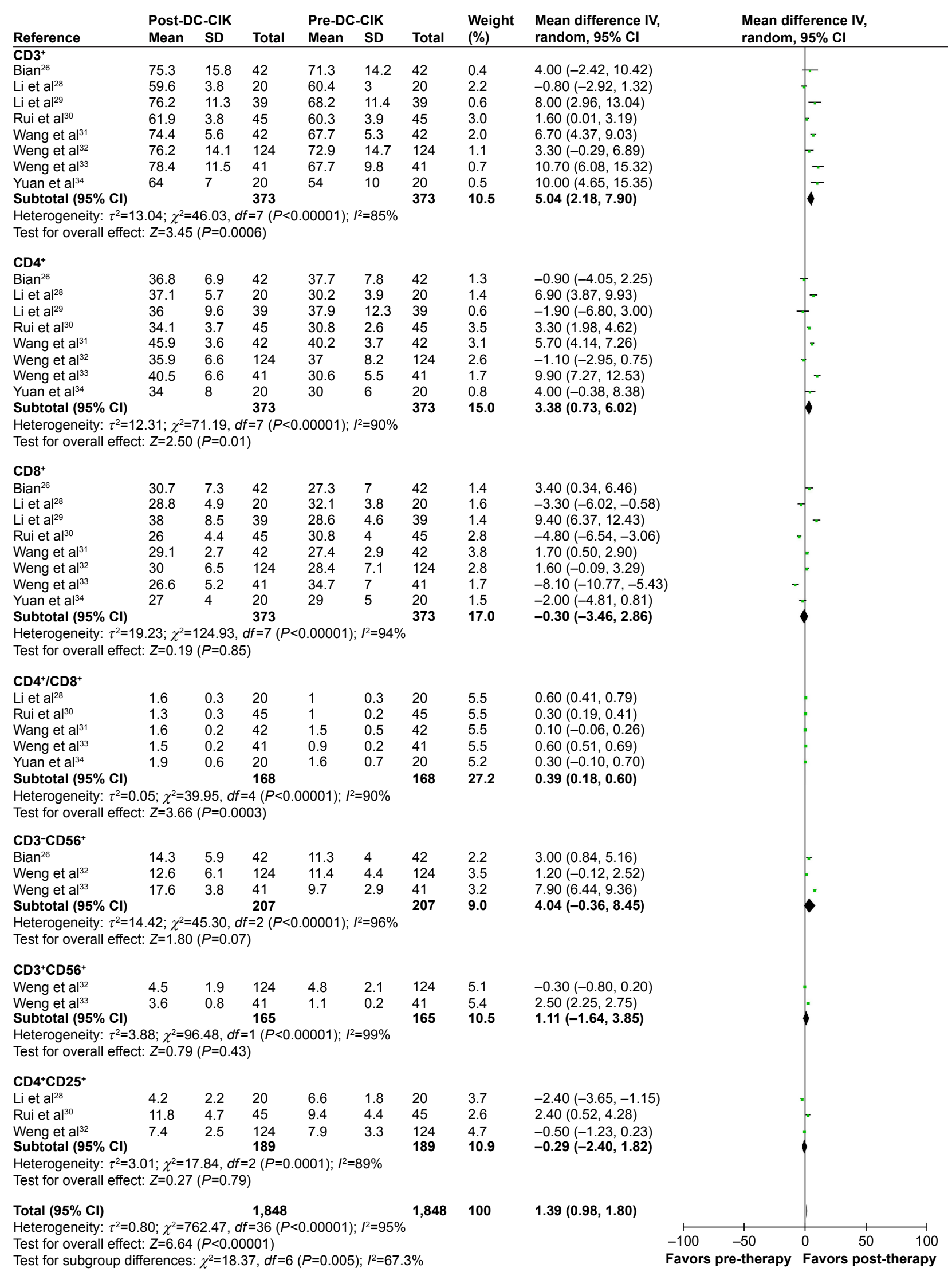

Figure 6 Forest plot of the comparison of immunophenotype in pre- and post-DC-CIK immunotherapy. The patient data were obtained before (pre-DC-CIK) and after DC-CIK treatment (post-DC-CIK). The random-effects meta-analysis model (IV method) was used.

Abbreviations: DC-CIK, dendritic cells and cytokine-induced killer cells; SD, standard deviation; IV, inverse variance; $\mathrm{Cl}$, confidence interval. 


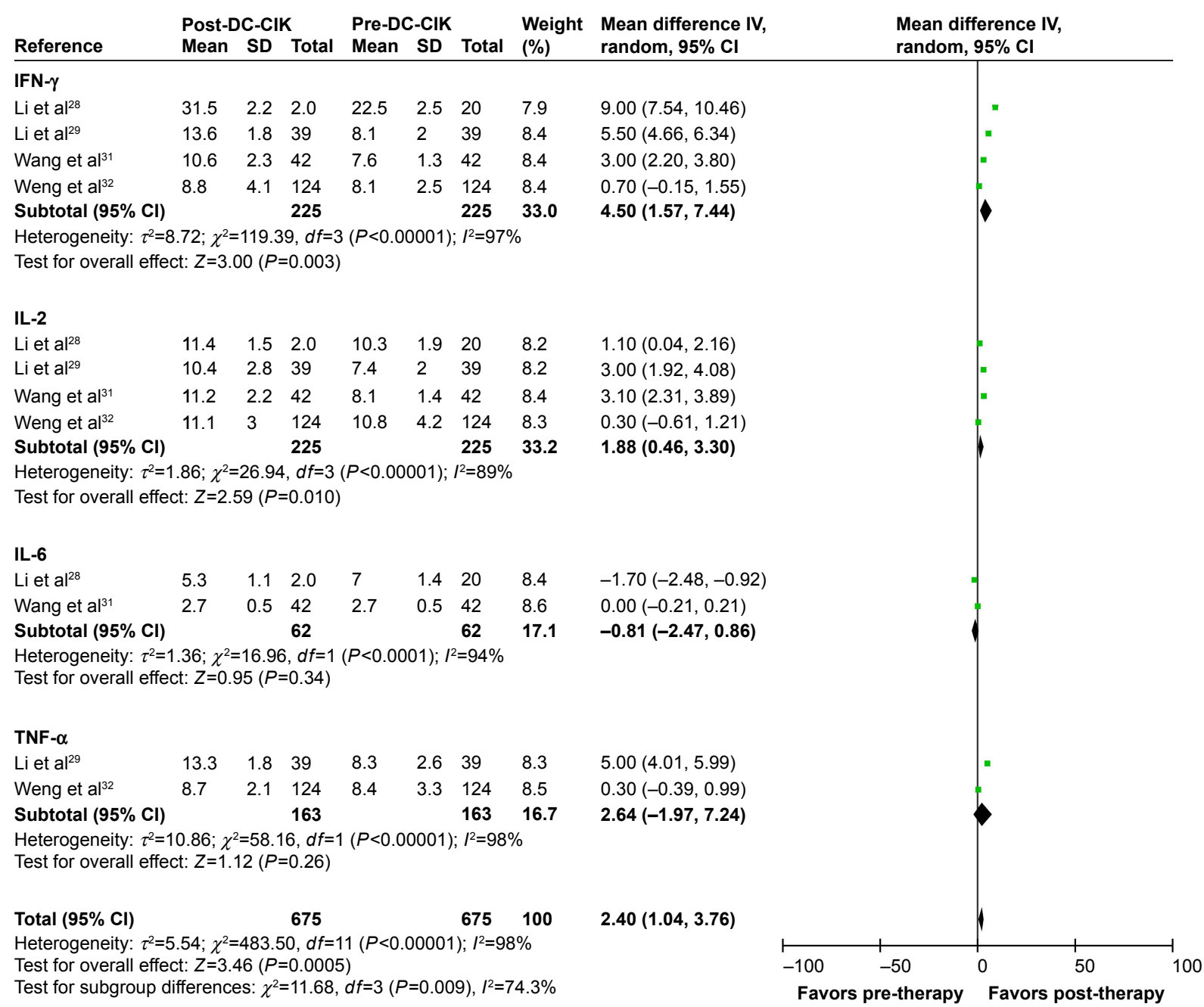

Figure 7 Forest plot of the comparison of cytokines in pre- and post-DC-CIK immunotherapy. The patient data were obtained before (pre-DC-CIK) and after DC-CIK treatment (post-DC-CIK). The random-effects meta-analysis model (IV method) was used.

Abbreviations: DC-CIK, dendritic cells and cytokine-induced killer cells; SD, standard deviation; IV, inverse variance; Cl, confidence interval.

Safety is a key factor to be considered in clinical treatment. Patients in combination group showed milder adverse events than those treated by FOLFOX alone. FOLFOX caused myelosuppression and gastrointestinal adverse reactions which were alleviated by DC-CIK immunotherapy $(P<0.05)$, but relief from other adverse events was not obtained. DC-CIK immunotherapy also enhanced the efficiency of FOLFOX in treating CRC. Compared to patients treated by FOLFOX alone, patients treated with combined therapy showed markedly increased 2-year OS, ORR, and DCR. Tumor markers, as the main factor for evaluation of therapeutic effects and prediction of recurrence and prognosis, ${ }^{36-39}$ also showed promising results with combined therapy. The levels of CEA, CA199, and CA242 were decreased after DC-CIK immunotherapy, although changes in the latter two were not statistically significant.

Immune reconstitution is important for treating malignancies. ${ }^{6} \mathrm{CD}^{+} \mathrm{T}$ cells assist in the recruitment of
$\mathrm{CD} 8^{+} \mathrm{T}$ cells and activate macrophages through the secretion of immune-regulatory cytokines, including IL-2, IL-12, and IFN- $\gamma$, thereby inducing tumor cell death. ${ }^{6,40}$ This also indicates a synergistic relationship between $\mathrm{CD}^{+}$and $\mathrm{CD} 8^{+}$cells in immune responses. ${ }^{40}$ It was found that the ratios of T-lymphocyte subsets were disordered in tumor patients. ${ }^{6,40}$ This analysis showed significantly increased percentages of $\mathrm{CD}^{+}$and $\mathrm{CD}^{+}$cells and $\mathrm{CD}^{+} / \mathrm{CD}^{+}$ratio upon DC-CIK treatment, indicating that the immune function of CRC patients was improved upon DC-CIK immunotherapy. Moreover, the antitumor activity of immune cells was associated with higher percentages of $\mathrm{CD}^{-} \mathrm{CD} 56^{+}$and $\mathrm{CD}^{+}{ }^{+} \mathrm{CD} 56^{+}$cells $^{6}$ and lower percentages of $\mathrm{CD} 4^{+} \mathrm{CD} 25^{+}$ regulatory T cells. ${ }^{41}$ In this meta-analysis, no significant difference was found in the percentages of $\mathrm{CD}^{+}, \mathrm{CD} 3^{-} \mathrm{CD} 56^{+}$, $\mathrm{CD}^{+}{ }^{+} \mathrm{CD} 56^{+}$, and $\mathrm{CD} 4{ }^{+} \mathrm{CD} 25^{+} \mathrm{T}$ cells between pre- and postimmunotherapy. This may be related to the various DC-CIK transfusion dosages and different time points of lymphocyte 


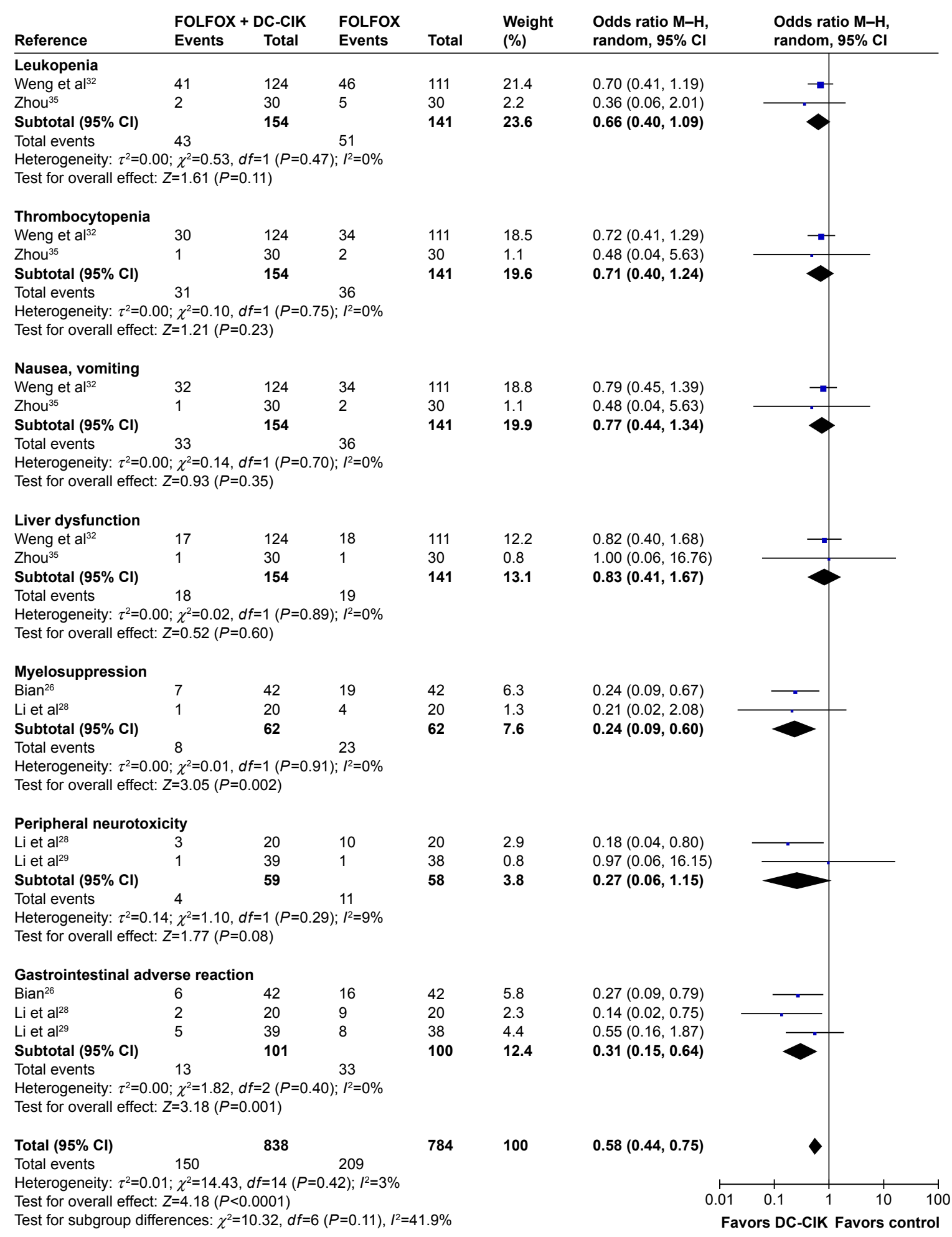

Figure 8 Forest plot of the comparison of adverse effects between the patients who received FOLFOX + DC-CIK therapy and those who received FOLFOX alone. The random-effects meta-analysis model (Mantel-Haenszel method) was used.

Abbreviations: FOLFOX, oxaliplatin, 5-fluorouracil, and leucovorin; DC-CIK, dendritic cells and cytokine-induced killer cells; M-H, Mantel-Haenszel method; Cl, confidence interval.

subset tests among these trials. ${ }^{8}$ Furthermore, the balance between Th1 and Th2 cells is crucial in immunotherapy. ${ }^{7}$ Th1 cytokines, including IFN- $\gamma$, IL-2, and TNF- $\alpha$, enhance the cytotoxicity of CIK, whereas Th2 cytokines, such as IL-6 and IL-10, are associated with tumor immune escape. ${ }^{42,43}$ The present analysis showed that after DC-CIK immunotherapy, the levels of IFN- $\gamma$ and IL-2 were significantly increased, whereas no significant differences were observed in TNF- $\alpha$ 
and IL-6, indicating an important role of IFN- $\gamma$ and IL-2 in DC-CIK immunotherapy.

\section{Limitations}

There are some limitations in our study. The 10 trials meeting the selection criteria were all conducted on a Chinese population. This may be because the large number of Chinese CRC patients has made CRC a research focus in China and led to there being many papers on it. Although the effectiveness of DC-CIK immunotherapy in various malignant tumors has been wildly reported, ${ }^{44-46}$ its usage in $\mathrm{CRC}$ is still rare outside of China. One German trial was included in this meta-analysis originally, but it was excluded due to insufficient data. ${ }^{47} \mathrm{We}$ will keep up with the future research and carry outfurther analyses of studies conducted both in and outside of China. Moreover, this analysis did not go through an open external evaluation, which may have led to an overestimation of treatment effects. Finally, the different treatment dosages and cycles of DC-CIK immunotherapy may have led to different clinical responses, ${ }^{19}$ but we were not able to obtain accurate information from some of the involved trials. Due to the above-mentioned limitations of this meta-analysis, further studies are needed to verify the safety and efficacy of the combined therapy strategy.

\section{Conclusion}

Taken together, this study confirms that FOLFOX regimen plus DC-CIK immunotherapy is a safe and effective treatment for CRC patients. It markedly prolongs patient's survival time and improves the efficacy of CRC treatment by reconstructing the patient's immune system. Therefore, the combination of FOLFOX chemotherapy regimen and DC-CIK immunotherapy is a promising treatment option for CRC patients.

\section{Author contributions}

All authors contributed toward data analysis, drafting, and critically revising the paper and agree to be accountable for all aspects of the work.

\section{Disclosure}

The authors report no conflicts of interest in this work.

\section{References}

1. Chen YX, Yang Q, Kuang JJ, et al. Efficacy of adding bevacizumab in the first-line chemotherapy of metastatic colorectal cancer: evidence from seven randomized clinical trials. Gastroenterol Res Pract. 2014; 2014:1-8.

2. Geva R, Vecchione L, Tejpar S, Piessevaux H, Van Cutsem E, Prenen H. Bevacizumab plus chemotherapy as salvage treatment in chemorefractory patients with metastatic colorectal cancer. Onco Targets Ther. 2013;6: $53-58$.
3. Kim JS, Kim YG, Park EJ, et al. Cell-based immunotherapy for colorectal cancer with cytokine-induced killer cells. Immune Netw. 2016;16(2):99-108.

4. Guo Y, Xiong BH, Zhang T, Cheng Y, Ma L. XELOX vs. FOLFOX in metastatic colorectal cancer: an updated meta-analysis. Cancer Invest. 2016;34(2):94-104.

5. Colucci G, Gebbia V, Paoletti G, et al. Phase III randomized trial of FOLFIRI versus FOLFOX4 in the treatment of advanced colorectal cancer: a multicenter study of the Gruppo Oncologico Dell'Italia Meridionale. J Clin Oncol. 2005;23(22):4866-4875.

6. Mu Y, Zhou CH, Chen SF, et al. Effectiveness and safety of chemotherapy combined with cytokine-induced killer cell/dendritic cell-cytokineinduced killer cell therapy for treatment of gastric cancer in China: a systematic review and meta-analysis. Cytotherapy. 2016;18(9):1162-1177.

7. Mu Y, Wang WH, Xie JP, Zhang YX, Yang YP, Zhou CH. Efficacy and safety of cord blood-derived dendritic cells plus cytokine-induced killer cells combined with chemotherapy in the treatment of patients with advanced gastric cancer: a randomized Phase II study. Onco Targets Ther. 2016;9:4617-4627.

8. Zhou CL, Liu DL, Li J, et al. Chemotherapy plus dendritic cells cocultured with cytokine-induced killer cells versus chemotherapy alone to treat advanced non-small-cell lung cancer: a meta-analysis. Oncotarget. 2016;7(52):86500-86510.

9. Zhao Z, Liao H, Ju Y. Effect of compound Kushen injection on T-cell subgroups and natural killer cells in patients with locally advanced nonsmall-cell lung cancer treated with concomitant radiochemotherapy. $J$ Tradit Chin Med. 2016;36(1):14-18.

10. Dudley ME, Gross CA, Somerville RP, et al. Randomized selection design trial evaluating $\mathrm{CD} 8+$-enriched versus unselected tumorinfiltrating lymphocytes for adoptive cell therapy for patients with melanoma. J Clin Oncol. 2013;31(17):2152-2159.

11. Chia WK, Teo M, Wang WW, et al. Adoptive T-cell transfer and chemotherapy in the first-line treatment of metastatic and/or locally recurrent nasopharyngeal carcinoma. Mol Ther. 2014;22(1):132-139.

12. Artene SA, Turcu-Stiolica A, Hartley R, et al. Dendritic cell immunotherapy versus bevacizumab plus irinotecan in recurrent malignant glioma patients: a survival gain analysis. Onco Targets Ther. 2016;9: 6669-6677.

13. Jakel CE, Schmidt-Wolf IG. An update on new adoptive immunotherapy strategies for solid tumors with cytokine-induced killer cells. Expert Opin Biol Ther. 2014;14(7):905-916.

14. Zhong R, Han B, Zhong H. A prospective study of the efficacy of a combination of autologous dendritic cells, cytokine-induced killer cells, and chemotherapy in advanced non-small cell lung cancer patients. Tumour Biol. 2014;35(2):987-994.

15. Wei XC, Yang DD, Han XR, et al. Bioactivity of umbilical cord blood dendritic cells and anti-leukemia effect. Int J Clin Exp Med. 2015; 8(10):19725-19730.

16. Li H, Ren XB, Zhang P, An XM, Liu H, Hao XS. [Dendritic cells reduce the number and function of CD4+CD25+ cells in cytokine-induced killer cells]. Zhonghua Yi Xue Za Zhi. 2005;85(44):3134-3138. Chinese [with English abstract].

17. Schmidt J, Eisold S, Buchler MW, Marten A. Dendritic cells reduce number and function of CD4+CD25+ cells in cytokine-induced killer cells derived from patients with pancreatic carcinoma. Cancer Immunol Immunother. 2004;53(11):1018-1026.

18. Ge W, Li CH, Zhang W, et al. [Coculture of dendritic cell with cytokineinduced killer results in a significant increase in cytotoxic activity of CIK to tumor cells in vitro and in vivo]. Zhonghua Xue Ye Xue Za Zhi. 2004;25(5):277-280. Chinese [with English abstract].

19. Zhao H, Wang Y, Yu JP, et al. Autologous cytokine-induced killer cells improves overall survival of metastatic colorectal cancer patients: results from a phase II clinical trial. Clin Colorectal Cancer. 2016; 15(3):228-235.

20. Lin T, Song C, Chuo DY, Zhang H, Zhao J. Clinical effects of autologous dendritic cells combined with cytokine-induced killer cells followed by chemotherapy in treating patients with advanced colorectal cancer: a prospective study. Tumour Biol. 2016;37(4):4367-4372. 
21. Gao D, Li C, Xie X, et al. Autologous tumor lysate-pulsed dendritic cell immunotherapy with cytokine-induced killer cells improves survival in gastric and colorectal cancer patients. PLoS One. 2014;9(4):e93886.

22. Wang ZX, Cao JX, Liu ZP, et al. Combination of chemotherapy and immunotherapy for colon cancer in China: a meta-analysis. World $J$ Gastroenterol. 2014;20(4):1095.

23. Zeng X, Zhang Y, Kwong JS, et al. The methodological quality assessment tools for preclinical and clinical studies, systematic review and meta-analysis, and clinical practice guideline: a systematic review. J Evid Based Med. 2015;8(1):2-10.

24. Han RX, Liu X, Pan P, Jia YJ, Yu JC. Effectiveness and safety of chemotherapy combined with dendritic cells co-cultured with cytokineinduced killer cells in the treatment of advanced non-small-cell lung cancer: a systematic review and meta-analysis. PLoS One. 2014;9(9) e108958.

25. Jackson D, White IR, Riley RD. Quantifying the impact of betweenstudy heterogeneity in multivariate meta-analyses. Stat Med. 2012; 31(29):3805-3820.

26. Bian JR. Study on chemotherapy combined with DC-CIK on colorectal cancer. Chin J Surg Oncol. 2013;5(5):306-309.

27. Hou ZY. Clinical study of DC-CIK combined with chemotherapy in the treatment of colon cancer. Guide China Med. 2015;13(35):64-65.

28. Li S, Li Y, Liang J, Liu XL. The study of clinical application of DCCIK combined with chemotherapy on colon cancer. Chin J Immunol. 2012;28(9):835-839.

29. Li WW, Zhang HP, Wu M. Study on DC-CIK cells combined with intravenous chemotherapy for advanced colorectal cancer with diffuse hepatic metastasis. Mod J Integr Tradit Chin West Med. 2016;25(18) 1942-1945.

30. Rui T, Wu GQ, Xu J, Zheng AH, Wu H, Ye ZY. Activated DC combined with CIK immunotherapy for patients with advanced colorectal cancer. Zhejiang Med J. 2015;18:1505-1509.

31. Wang R, Yi M, Yang SR, Chai LX, Hua M. The influence of DC-CIK in advanced colorectal cancer patients on $\mathrm{T}$ lymphocyte subsets and cytokines. J Hainan Med Univ. 2016;22(14):1580-1583.

32. Weng HG, Shen D, Mao WD, Han LX. Clinical efficacy of DC-CIK immunotherapy combined with chemotherapy in treatment of advanced colorectal cancer. Zhejiang Med J. 2015;8:626-629.

33. Weng JF, Yu LW, Li YP, Shi YQ, Pu YD, Cao ZY. Clinical observation of co-treatment with CIK cells and dendritic cells for advanced rectal cancer. Chin J Clin Oncol Rehabil. 2014;21(9):1040-1043.

34. Yuan JH, Peng DW, Li JW, Wang MQ. Clinical research of dendritic cells combined with cytokine induced killer cells therapy for advanced colorectal cancer. Chin Gen Pract. 2011;36:4139-4141.
35. Zhou QM. Observation effect of biological immune method in the treatment of patients with advanced colorectal cancer. China Mod Med. 2015;22(34):37-39.

36. Levy M, Visokai V, Lipska L, Topolcan O. Tumor markers in staging and prognosis of colorectal carcinoma. Neoplasma. 2008;55(2):138-142.

37. Wang RF, Song BR, Peng JJ, et al. The prognostic value of preoperative serum CEA and CA19-9 values in stage I-III colorectal cancer. Hepatogastroenterology. 2014;61(132):994-999.

38. Yang XQ, Chen C, Peng CW, Liu SP, Li Y. Carbohydrate antigen 242 highly consists with carbohydrate antigen 19-9 in diagnosis and prognosis of colorectal cancer: study on 185 cases. Med Oncol. 2012;29(2): 1030-1036.

39. Zhang SY, Lin M, Zhang HB. Diagnostic value of carcinoembryonic antigen and carcinoma antigen 19-9 for colorectal carcinoma. Int J Clin Exp Pathol. 2015;8(8):9404-9409.

40. Wang M, Cao JX, Pan JH, et al. Adoptive immunotherapy of cytokineinduced killer cell therapy in the treatment of non-small cell lung cancer. PLoS One. 2014;9(11):e112662.

41. Liu H, Li J, Wang F, et al. Comparative study of different procedures for the separation of peripheral blood mononuclear cells in cytokine-induced killer cell immunotherapy for hepatocarcinoma. Tumour Biol. 2015; 36(4):2299-2307.

42. Dulos J, Carven GJ, van Boxtel SJ, et al. PD-1 blockade augments Th1 and Th17 and suppresses Th2 responses in peripheral blood from patients with prostate and advanced melanoma cancer. J Immunother. 2012;35(2):169-178.

43. Wang ZX, Cao JX, Wang M, et al. Adoptive cellular immunotherapy for the treatment of patients with breast cancer: a meta-analysis. Cytotherapy. 2014;16(7):934-945.

44. Olioso P, Giancola R, Di Riti M, Contento A, Accorsi P, Iacone A. Immunotherapy with cytokine induced killer cells in solid and hematopoietic tumours: a pilot clinical trial. Hematol Oncol. 2009;27(3):130-139.

45. Lee JH, Lim YS, Yeon JE, et al. Adjuvant immunotherapy with autologous cytokine-induced killer cells for hepatocellular carcinoma. Gastroenterology. 2015;148(7):1383-1391e6.

46. Linn YC, Niam M, Chu S, et al. The anti-tumour activity of allogeneic cytokine-induced killer cells in patients who relapse after allogeneic transplant for haematological malignancies. Bone Marrow Transplant. 2012;47(7):957-966.

47. Schmidt-Wolf IG, Finke S, Trojaneck B, et al. Phase I clinical study applying autologous immunological effector cells transfected with the interleukin-2 gene in patients with metastatic renal cancer, colorectal cancer and lymphoma. Br J Cancer. 1999;81(6):1009-1016. 


\section{Supplementary material}

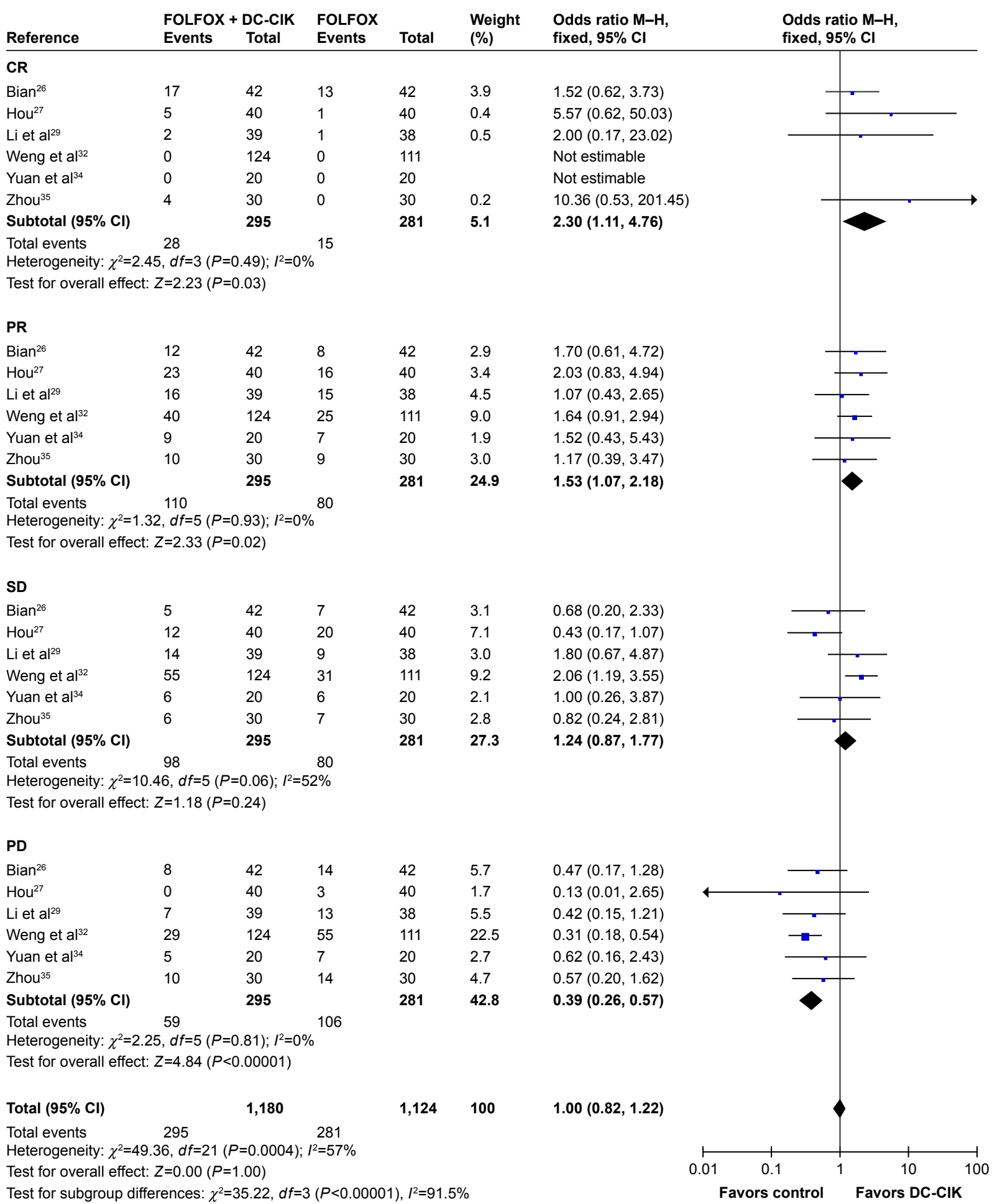

Figure SI Forest plot of the comparison of CR, PR, SD, and PD between the patients who received FOLFOX + DC-CIK therapy and those who received FOLFOX alone. The fixed-effects meta-analysis model (Mantel-Haenszel method) was used.

Abbreviations: CR, complete response rate; PR, partial response rate; SD, stable disease rate; PD, progressive disease rate; FOLFOX, oxaliplatin, 5-fluorouracil, and leucovorin; DC-CIK, dendritic cells and cytokine-induced killer cells; $\mathrm{M}-\mathrm{H}$, Mantel-Haenszel method; Cl, confidence interval. 
OncoTargets and Therapy

\section{Publish your work in this journal}

OncoTargets and Therapy is an international, peer-reviewed, open access journal focusing on the pathological basis of all cancers, potential targets for therapy and treatment protocols employed to improve the management of cancer patients. The journal also focuses on the impact of management programs and new therapeutic agents and protocols on

ient perspectives such as quality of life, adherence and satisfaction. The manuscript management system is completely online and includes a very quick and fair peer-review system, which is all easy to use. Visit http://www.dovepress.com/testimonials.php to read real quotes from published authors.

Submit your manuscript here: http://www.dovepress.com/oncotargets-and-therapy-journal 